\title{
Annual nitrogen budget of the seagrass Posidonia oceanica as determined by in situ uptake experiments
}

\author{
Gilles Lepoint*, Sylvie Millet, Patrick Dauby, Sylvie Gobert, Jean-Marie Bouquegneau \\ Oceanology, B6, University of Liège, 4000 Liège, Belgium
}

\begin{abstract}
The uptake of nitrate and ammonium by the roots and leaves of Posidonia oceanica were determined between February 1997 and June 1999 by in situ experiments using the isotope 15 of nitrogen $\left({ }^{15} \mathrm{~N}\right)$ as a tracer in a nutrient-poor coastal zone of the NW Mediterranean Sea (Revellata Bay, Corsica). Nitrate and ammonium leaf uptakes are recorded at 0.05 and $0.1 \mu \mathrm{M}$ respectively. The high variability observed cannot be explained solely by the variation of the substrate concentrations in the water column. For leaves, mean specific uptake rates were $47 \pm 45$ and $43 \pm 64 \mu g \mathrm{~N} \mathrm{~g} \mathrm{~N}^{-1} \mathrm{~h}^{-1}$. Nitrate and ammonium leaf uptake fluxes $\left(\mathrm{g} \mathrm{N} \mathrm{m}^{-2} \mathrm{yr}^{-1}\right)$ seem to have the same importance on an annual basis. Nitrate uptake occurs mainly in winter and early spring, when nitrate concentrations in the water column are highest. The uptake of $\mathrm{N}$, and mainly of ammonium, is significant throughout the year with maxima at the beginning of spring, but it is insufficient to meet the annual N requirement of the plant. Posidonia root biomass was very high and corresponded to high specific N uptake rates by the roots. Ammonium was incorporated by the roots 6 times faster than nitrate. In the sediment, this uptake capacity is limited by the nutrient diffusion rate, and the root uptake is therefore insufficient to meet the $\mathrm{N}$ requirements of the plant. In fact, $P$. oceanica of Revellata Bay have a complex $\mathrm{N}$ budget involving uptake and recycling processes and allowing the plants to meet their $\mathrm{N}$ requirements in one of the most nutrient-poor areas of the NW Mediterranean Sea. We calculated that leaf and root would contribute to 40 and $60 \%$ of the annual $\mathrm{N}$ uptake, respectively, and $60 \%$ of the annual $\mathrm{N}$ requirement of the plant.
\end{abstract}

KEY WORDS: Seagrass · Nitrogen uptake $\cdot{ }^{15} \mathrm{~N}$ tracer $\cdot \mathrm{NW}$ Mediterranean

\section{INTRODUCTION}

Seagrasses are among the most productive marine primary producers per unit area (Duarte \& Chiscano 1999). Therefore, the nutrient needs of seagrasses are relatively high, although their nitrogen and phosphorus contents are low compared to other marine producers (Duarte 1990, Stapel et al. 2001). Many seagrass meadows are located in nutrient-poor coastal areas, where seagrasses are good competitors compared to phytoplankton and fast-growing benthic algae (Cloern 2001).

*E-mail: g.lepoint@ulg.ac.be
Seagrasses have several mechanisms to satisfy their nutrient requirements. Uptake rates of inorganic $\mathrm{N}$ and $\mathrm{P}$ are significant even in very nutrient-poor environments (Stapel et al. 1996). Many species have nutrient storage strategies (i.e. uptake of nutrients when available, storage and use of reserves when environmental conditions become adequate for plant growth; e.g. Kraemer \& Mazzella 1999, Alcoverro et al. 2000). This strategy allows seagrass species, in particular large species with a long life span, to 'buffer' a scarcity of nutrients in the environment (Marba et al. 1996). Internal recycling (i.e. resorption and remobilisation of nutrients from old leaves to contribute to young leaf growth) is 1 such process used by sea- 


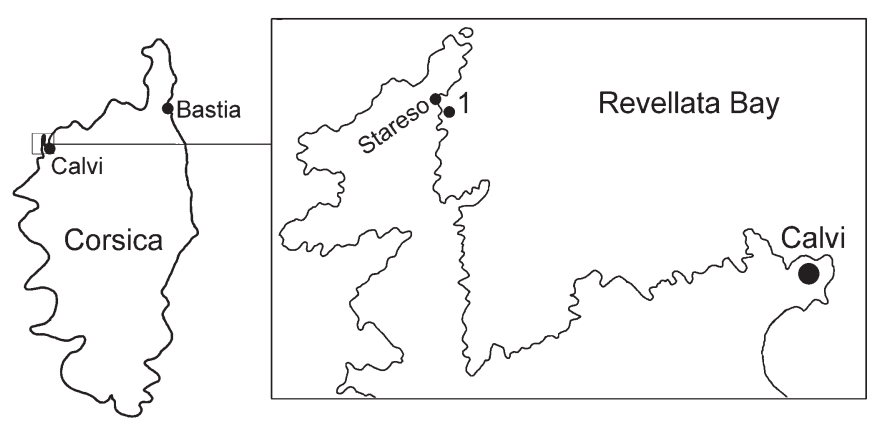

Fig. 1. Location of the experimental site (1) in Revellata Bay (Gulf of Calvi, Corsica, France) at $10 \mathrm{~m}$ depth in front of the oceanographic station STARESO

grasses to meet their nutrient requirements (Hemminga et al. 1999).

Some species take up inorganic nitrogen only through their leaves (e.g. Phyllospadix torreyi; Terrados \& Williams 1997) or their roots. In Thalassia hemperichii, roots and leaves are of similar importance in N uptake (Lee \& Dunton 1999a). In Zostera marina, annual populations show only uptake by the leaves, but perennial populations with greater root biomass have significant root and leaf uptakes (Pedersen \& Borum 1993, Hemminga et al. 1994).

Posidonia oceanica is a large seagrass, endemic to the Mediterranean Sea and living in very nutrient-poor areas. It has a very great root biomass, and the ratio between the maximum of root biomass and leaf biomass is the highest among seagrasses (Duarte \& Chiscano 1999). To determine an annual $\mathrm{N}$ budget for $P$. oceanica, we measured the uptake of nitrate and ammonium by the roots and the leaves of the plant. We performed in situ experiments, using the isotope 15 of nitrogen $\left({ }^{15} \mathrm{~N}\right)$ as a tracer, in one of the most nutrientpoor areas in the NW Mediterranean (Revellata Bay, Calvi, Corsica).

\section{MATERIALS AND METHODS}

Study site. All samplings and measurements were done in Revellata Bay (Gulf of Calvi, Corsica, France) near the marine research station STARESO (Fig. 1). The bay opens to the northeast, has a surface area of approximately 245 ha and an average depth of $40 \mathrm{~m}$ (maximum about $60 \mathrm{~m}$ ). The seafloor drops gradually ( $2 \%$ slope) from south to northeast. An extensive Posidonia oceanica meadow covers about 180 ha of the sandy seafloor, reaching $38 \mathrm{~m}$ depth (Bay 1984). The seagrass bed of Revellata Bay has been studied since the 1970s (e.g. Bay 1984, Dalla Via et al. 1998, Gobert et al. 2001).
The sea surface temperature ranges from $12^{\circ} \mathrm{C}(\mathrm{Feb}-$ ruary-March) to $26^{\circ} \mathrm{C}$ (August-September) with an annual mean of $18.1^{\circ} \mathrm{C}$ (STARESO data, Lepoint 2001). The water column is strongly stratified from May to October, with the thermocline around 25 to $30 \mathrm{~m}$ depth (range: 20 to $50 \mathrm{~m}$, depending on wind conditions). Water residence time in the bay varies from $5 \mathrm{~d}$ in winter to $10 \mathrm{~d}$ in summer (Norro 1995).

Uptake measurements. All experiments were carried out in situ at $10 \mathrm{~m}$ depth (Fig. 1). Nitrate and ammonium uptake by the leaves and roots of the seagrass Posidonia oceanica was measured in 1997 and 1998 during February, June and October, and in 1999 from February to June.

Nitrogen uptake by the leaves was measured with an experimental device composed of 2 transparent Plexiglas cylinders and a submerged pump to recirculate the water (about 8 l; Fig. 2). One cylinder was placed vertically on an open base made of PVC and driven into the sediment $24 \mathrm{~h}$ before the experiment to isolate a Posidonia oceanica shoot. A rubber membrane separated the cylinder into a leaf and a sediment chamber. Experiments were done in duplicate (i.e. addition of same nutrient at same concentration).

To measure uptake by the roots, Posidonia oceanica shoots were uprooted $24 \mathrm{~h}$ before the experiments and placed in an experimental device consisting of a leaf compartment (transparent Plexiglas bell of 41 volume) placed on a root compartment (closed dark chamber of PVC, 21 volume). A rubber membrane separated the 2 compartments, and the pump was connected to the root chamber.

All experiments had a duration of $1 \mathrm{~h}$. The ${ }^{15} \mathrm{~N}$ tracers were solutions of ammonium sulphate $\left(99.0 \%{ }^{15} \mathrm{~N}\right)$ or sodium nitrate $\left(99.0 \%{ }^{15} \mathrm{~N}\right)$ (Eurisotop, France). For

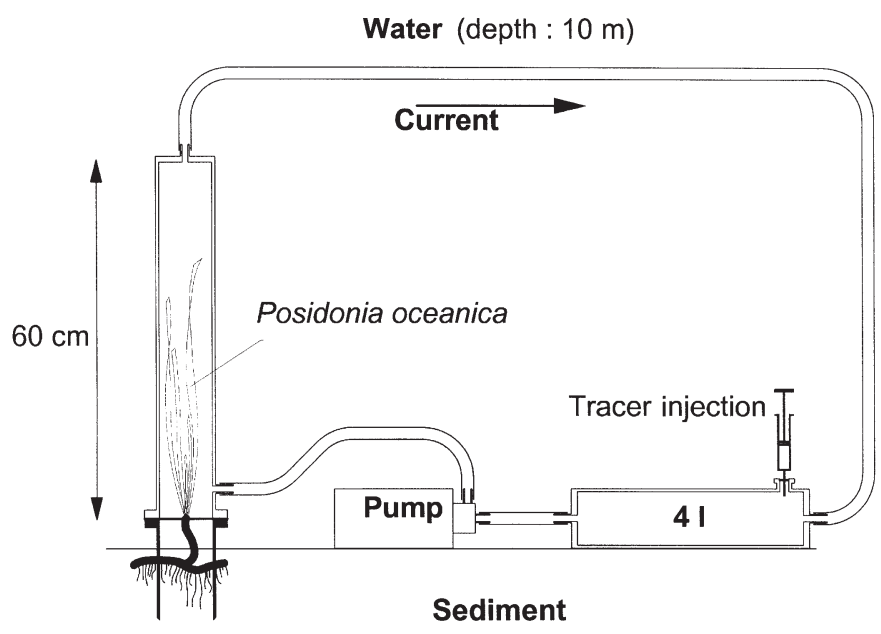

Fig. 2. Experimental device used to measure the in situ uptake of ${ }^{15} \mathrm{~N}$ by leaves 
leaf uptake measurements, when the ambient concentrations of ${ }^{15} \mathrm{~N}$ were near the detection limits, the tracer was added to a final concentration of about $0.05 \mu \mathrm{M}$. In other conditions, we tried to add a minimum of tracer which generally corresponded to 10 to $20 \%$ of the initial ambient concentration.

In root uptake measurements, tracer was added to a final concentration representative of pore water concentrations (2 to $4 \mu \mathrm{M}$ ).

Water samples for nutrient concentration measurements were taken from the cylinder before and $5 \mathrm{~min}$ after adding the tracer, and at the end of the experiment.

After sampling, the Posidonia leaves were scrapped with a razor blade to remove epiphytes. Posidonia organs were briefly rinsed with distilled water to remove adsorpted ${ }^{15} \mathrm{~N}$, oven-dried at $60^{\circ} \mathrm{C}$ for $48 \mathrm{~h}$ and weighed.

Samples were finely ground for spectrometric and elemental analysis. These measurements were done in triplicate for leaves, roots and rhizomes from each experiment, using an isotopic ratio mass spectrometer (Optima, Micromass) coupled to a C-N-S elemental analyser (Carlo Erba). Nitrate and ammonium concentrations in water samples were measured colorimetrically with an automated analytical chain (Technicon, or Skalar). Analytical precision was $0.01 \mu \mathrm{M}$ for nitrate and $0.05 \mu \mathrm{M}$ for ammonium.

Leaf biomasses in the field were measured during each campaign on the sampling site. Biomasses were calculated on the basis of density and dry weight of the shoots. The density was determined during each campaign using a $40 \mathrm{~cm}$ hoop randomly thrown in the meadow. We observed no significant change in density during this study $\left(\mathrm{n}=259,402 \pm 140\right.$ shoots $\left.\mathrm{m}^{-2}\right)$. Dry weight of the shoots was measured during each campaign, and monthly in 1999 (10 shoots randomly collected + experimental shoots). Belowground biomass was measured in June 1999 at 12 m depth on 4 samples of mats $(30 \times 30 \times 30 \mathrm{~cm})$. Dead and living material were separated according to the following criteria: connection or absence of connection of the roots and rhizomes to a living shoot with leaves; appearance of roots and rhizomes connected to a living shoot (dead roots and rhizomes are black, often empty or rotten inside; living rhizomes are usually pink inside and living roots are brown).

Dry weight biomass was converted to $\mathrm{N}$ biomass using elemental data (monthly averages).

Calculations. Specific uptake rates $V\left(\mu g \mathrm{Ng} \mathrm{N}^{-1} \mathrm{~h}^{-1}\right)$ and uptake fluxes $\rho\left(\mu \mathrm{g} \mathrm{N} \mathrm{m}{ }^{-2} \mathrm{~h}^{-1}\right)$ were calculated after Collos (1987):

$$
V=\frac{A_{\mathrm{f}}-A_{0}}{A_{\mathrm{d}} \times t}=\frac{\rho}{\text { biomass } N}
$$

where $A_{\mathrm{f}}$ is the final ${ }^{15} \mathrm{~N}$ abundance measured in the plant, $A_{0}$ is the initial (= natural) ${ }^{15} \mathrm{~N}$ abundance in the plant, $A_{\mathrm{d}}$ is the ${ }^{15} \mathrm{~N}$ abundance in the dissolved phase at the beginning of the experiment, $t$ is the duration of the experiment, and biomass $N$ is the nitrogen biomass measured in the field. The conversion of biomasses (dry weight) to biomass $N$ was done using averaged $\mathrm{N}$ measurements. In Revellata Bay, the natural abundance $\left(A_{0}\right)$ of ${ }^{15} \mathrm{~N}$ in Posidonia oceanica shoots was $0.36728 \pm 0.0005 \%{ }^{15} \mathrm{~N}$ (i.e. $+2.6 \%$ in $\delta$ notation; Lepoint et al. 2000). The experimental particulate material is considered as enriched in ${ }^{15} \mathrm{~N}$ relative to natural ${ }^{15} \mathrm{~N}$ concentrations when $A_{\mathrm{f}}-A_{0} \geq 0.001 \%{ }^{15} \mathrm{~N}$. $A_{\mathrm{d}}$ was considered constant during the experiment $(1 \mathrm{~h})$ and calculated according to the isotopic mixing equation:

$$
C_{\mathrm{d}} \times A_{\mathrm{d}}=A_{\mathrm{d}_{0}} \times C_{\mathrm{d}_{0}}+A_{t} \times C_{t}
$$

where $C_{\mathrm{d}}$ is the concentration of ammonium or nitrate in the dissolved phase after the ${ }^{15} \mathrm{~N}$ tracer addition, $A_{\mathrm{d}_{0}}$ and $C_{\mathrm{d}_{0}}$ are the natural ${ }^{15} \mathrm{~N}$ abundance and the initial concentration of nitrate or ammonium in the dissolved phase, respectively, and $A_{t}$ and $C_{t}$ are the ${ }^{15} \mathrm{~N}$ abundance $\left(99.0 \%{ }^{15} \mathrm{~N}\right)$ and the concentration of the added tracer, respectively. $A_{\mathrm{d}_{0}}$ was set at 0.37 , considering that the importance of natural variation of this term is small when compared to the variations of the tracer concentrations.

\section{RESULTS}

\section{Nutrient concentrations}

Water column concentrations of $\mathrm{NO}_{3}$ and $\mathrm{NH}_{4}$ were very low (Fig. 3). In 1999, a peak of nitrate was recorded at the beginning of spring, related to winter mixing of the water column and an occurrence of NE winds transporting deeper and nutrient-enriched waters from the open sea into the bay (Brohée et al. 1989, Skliris et al. 2001). The concentrations were in the range of values measured in other coastal waters of the NW Mediterranean (e.g. Delgado et al. 1994 on the Catalan coast of Spain, and Kraemer \& Mazzella 1999 in Ischia Bay, Italy).

During this study, S. Gobert et al. (unpubl.) measured the concentrations of $\mathrm{NO}_{3}$ and $\mathrm{NH}_{4}$ in the pore water of the seagrass meadow. These concentrations were higher than those in the water column (Fig. 3). $\mathrm{NH}_{4}$ concentrations were always higher than $\mathrm{NO}_{3}$ concentrations. The concentrations measured in Revellata Bay were in the same range as those measured by Cancemi et al. (2000) at another site of the western Corsican coast, but much lower than pore water concentrations at other coastal sites of the NW Mediterranean (e.g. Lopez et al. 1995, Kraemer \& Mazzella 

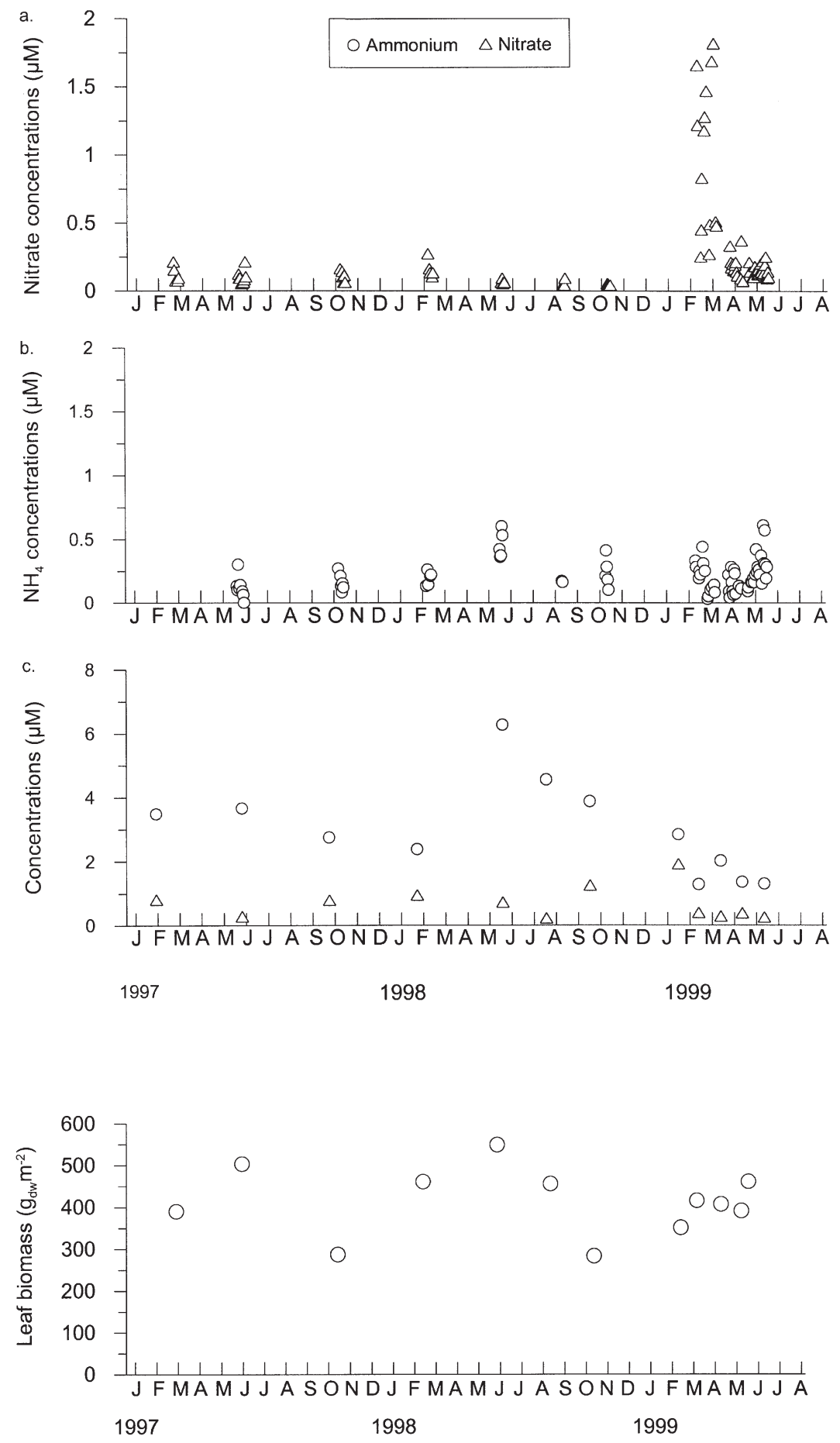

Fig. 3. Nitrate and ammonium concentrations measured in the water column $(a, b)$ and in the pore water (c) of the seagrass bed in Revellata Bay. Water column measurements correspond to the initial samplings made in the experimental chambers used for ${ }^{15} \mathrm{~N}$ uptake measurements. Pore water measurements were done by S. Gobert et al. (unpubl.) during our experimental work. Samples were taken using a $60 \mathrm{ml}$ syringe with a $10 \mathrm{~cm}$ nonox needle. Concentrations were measured as for water column samples after filtration on $\mathrm{GF} / \mathrm{C}$

Table 1. Posidonia oceanica. Belowground (mean $\pm \mathrm{SD}$ ) and maximum ( $\mathrm{g}$ dry $\mathrm{wt}^{-2}$ ) leaf biomass in Revellata Bay seagrass meadow. Belowground sampling $(\mathrm{n}=4)$ done in June 1999 at $12 \mathrm{~m}$ depth (sample volume: $30 \times 30 \times 30 \mathrm{~cm}$ )

\begin{tabular}{|lcccc|}
\hline Living biomass & Necromass & Total & Maximum leaf biomass & Belowground/leaf biomass ratio \\
\hline $3068 \pm 1909$ & $9914 \pm 2331$ & $12982 \pm 3340$ & 550 & 5.4 \\
\hline
\end{tabular}


1999). This low level of inorganic nitrogen in the pore water of the sediment along the western Corsican coast is a notable characteristic of the ecosystem, as the sediment is often considered an important source of nutrients for benthic and pelagic primary producers.

\section{Posidonia oceanica leaf and belowground biomasses}

Leaf biomass shows a clear seasonal variation with minima in October and maxima in June (Fig. 4). In Revellata Bay, leaf biomass is generally lowest in winter and highest in early summer (Bay 1984) which corresponds to the pattern described for this species (e.g. Alcoverro et al. 1995). The average annual leaf biomass at $10 \mathrm{~m}$ depth was $413 \pm 80 \mathrm{~g}_{\mathrm{dw}} \mathrm{m}^{-2}$.

The belowground biomass measured in Revellata Bay is very important (Table 1). In June 1999 the leaf biomass constituted less than one-sixth of the total living biomass. The belowground material consists mainly of dead and living roots of Posidonia oceanica. Dead and living rhizomes were only a minor part of the material collected, although the proportion of rhizomes is usually greater than the proportion of roots (Mazzella et al. 1998). Large dead leaf fragments were absent, but leaf decay could be present as detritus in the fine material and sediment filling up the spaces between the roots and rhizomes (Mateo \& Romero 1997). The necromass forms two-thirds of the total biomass, which agrees with data from the literature (e.g. Mateo \& Romero 1997).

The $\mathrm{N}$ contents of the leaves $\left(\mathrm{mg} \mathrm{N}^{\mathrm{N}}\right.$ shoot $\left.^{-1}\right)$ show a strong seasonal pattern (Fig. 5) corresponding to the pattern described by Alcoverro et al. (1995). Values were lowest in October, and highest in June of 1997 and 1998, and March of 1999.

Relative $\mathrm{N}$ concentrations in the leaves (\% dry wt) were also highly variable (Fig. 5), with low values in
October and high values in February (i.e. before the maxima of leaf biomass and $\mathrm{N}$ content).

\section{Uptake experiments}

The minimum specific nitrogen uptake rate measured in situ in the Posidonia oceanica meadow was $10 \mu \mathrm{g} \mathrm{g} \mathrm{N}^{-1} \mathrm{~h}^{-1}$.

In Posidonia oceanica leaves, the average specific uptake rate of nitrate $V_{\mathrm{NO}_{3}}$ was not significantly different from that of ammonium $V_{\mathrm{NH}_{4}}$ (Table 2). During the study period, the $V_{\mathrm{NO}_{3}}$ were highest in early spring 1999 (160 $\mu \mathrm{g} \mathrm{N} \mathrm{g} \mathrm{N}^{-1} \mathrm{~h}^{-1}$ ) (Fig. 6). In some experiments, particularly in 1997, no $\mathrm{NO}_{3}$ uptake by leaves was detected.

The $V_{\mathrm{NH}_{4}}$ were generally equal to or lower than the $V_{\mathrm{NO}_{3}}$ (Fig. 6). An uptake of $\mathrm{NH}_{4}$ by Posidonia oceanica leaves was measured in all but 2 experiments (June 1997 and May 1999). The $V_{\mathrm{NH}_{4}}$ were highest in MarchApril 1999.

From February 1998, the specific uptake rates of the different types of leaves (Giraud 1979) were recorded separately. The average $V_{\mathrm{NO}_{3}}$ of the different leaf types are not significantly different from the $V_{\mathrm{NH}_{4}}$ (Table 2). The $V_{\mathrm{NO}_{3}}$ and $V_{\mathrm{NH}_{4}}$ of juvenile leaves were higher than those of adult and intermediate leaves (Table 2).

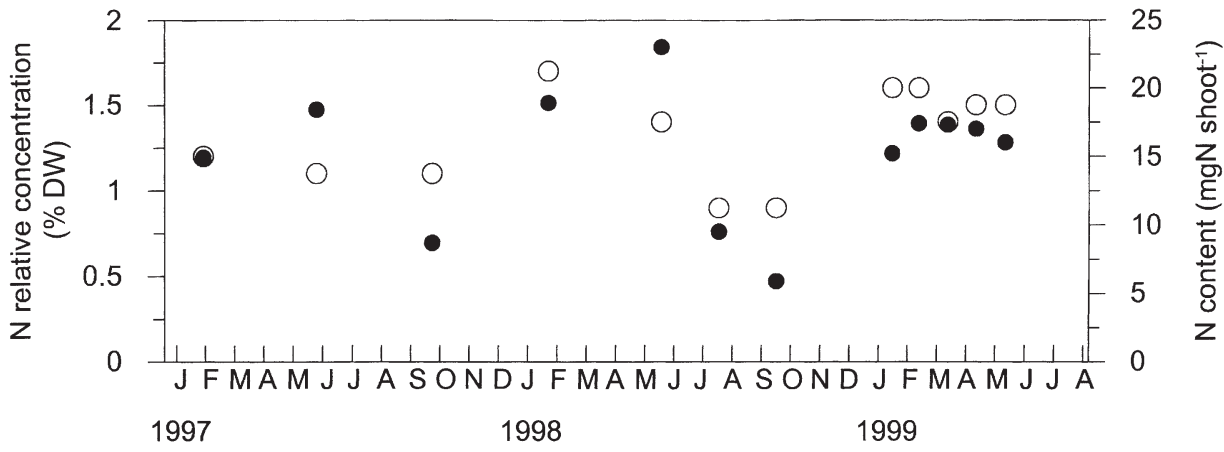

Fig. 5. Posidonia oceanica Monthly averages of the relative $\mathrm{N}$ concentrations $(\bullet)$ and the $\mathrm{N}$ content $(\mathrm{O})$ 

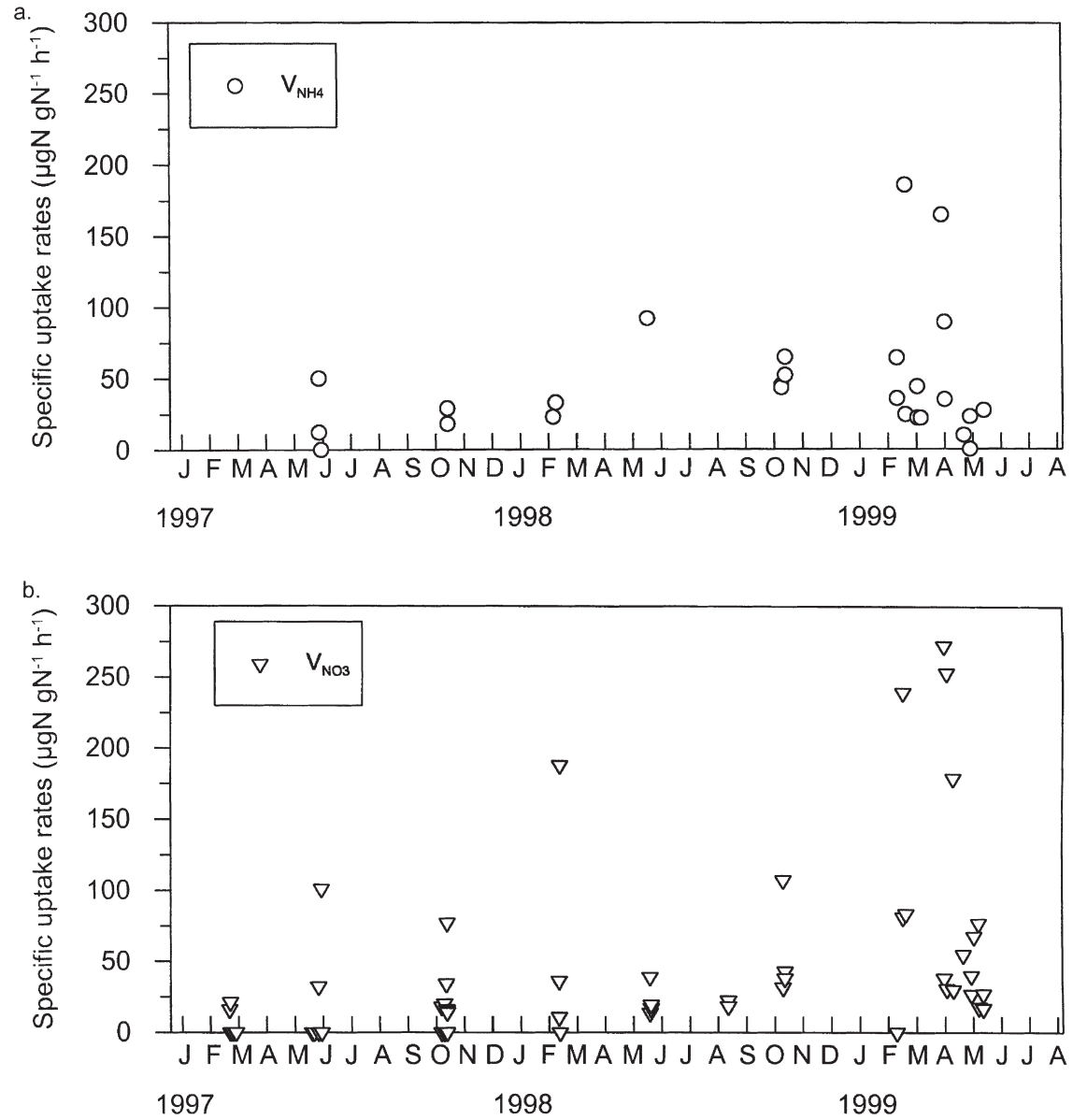

Fig. 6. Posidonia oceanica. Specific uptake rates of (a) ammonium and (b) nitrate by the leaves during ${ }^{15} \mathrm{~N}$ tracer experiments performed at $10 \mathrm{~m}$ depth in Revellata Bay between February 1997 and June 1999. Each value corresponds to 1 experiment
The average specific uptake rates of Posidonia oceanica roots are higher than those of the leaves (Table 3). The $V_{\mathrm{NH}_{4}}$ of roots are higher than the $V_{\mathrm{NO}_{3}}$.

\section{DISCUSSION}

The uptake rates measured in Posidonia oceanica are of the same order of magnitude as for other seagrasses (e.g. Pedersen et al. 1997). However, to our knowledge this study is the first attempt to measure the in situ uptake rate at ambient substrate concentrations. In nutrient-poor waters, uptake rates at ambient nutrient concentrations are generally calculated from the kinetic parameters of Michaelis-Menten curves (e.g. Stapel et al. 1996, Lee \& Dunton 1999a). The ${ }^{15} \mathrm{~N}$ method has 2 advantages: firstly, the addition of small amounts of ammonium or nitrate allows measurement of the $\mathrm{N}$ uptake at quasi-ambient nutrient concentrations. Secondly, the ${ }^{15} \mathrm{~N}$ measurement can be done separately by each of the producers present. It is therefore possible to discriminate between the uptake by the seagrass leaf and that of the epiphytes or other producers (such as phytoplankton), avoiding experimental artefacts (due to scraping off of epiphytes, or seawater filtration).

However, 2 main methodological errors could affect the measurements of the uptake rates: firstly, uncertainty in the nutrient concentration measurements used to calculate the initial ${ }^{15} \mathrm{~N}$ enrichment $\left(A_{d}\right)$ of the dissolved phase (Eq. 2) and, secondly, the isotopic dilution which affects this enrichment during the experiment (i.e. dilution of the dissolved ${ }^{15} \mathrm{~N}$ pool by ${ }^{14} \mathrm{NH}_{4}$

Table 3. Posidonia oceanica. Mean $( \pm$ SD) specific uptake rates of ammonium and nitrate by the leaves and roots. Nutrient concentrations are the mean concentrations measured in the root or in the leaf compartment after the ${ }^{15} \mathrm{~N}$ tracer additions. $\mathrm{n}=$ number of experiments

\begin{tabular}{|llccc|}
\hline & & $\begin{array}{c}\text { Specific } \\
\text { uptake rates } \\
\left(\mu \mathrm{g} \mathrm{N} \mathrm{N} \mathrm{N}^{-1} \mathrm{~h}^{-1}\right)\end{array}$ & $\begin{array}{c}\text { Nutrient } \\
\text { concentrations } \\
(\mu \mathrm{M})\end{array}$ & $\mathrm{n}$ \\
\hline Roots & $\mathrm{NH}_{4}$ & $484 \pm 540$ & $4.9 \pm 6.1$ & 20 \\
& $\mathrm{NO}_{3}$ & $76 \pm 70$ & $2.2 \pm 2.4$ & 27 \\
Leaves & $\mathrm{NH}_{4}$ & $47 \pm 45$ & $0.2 \pm 0.2$ & 26 \\
& $\mathrm{NO}_{3}$ & $43 \pm 64$ & $0.2 \pm 0.4$ & 58 \\
\hline
\end{tabular}


produced by remineralisation; see Glibert et al. 1982, Dugdale \& Wilkerson 1986). It is difficult to estimate the impact of these methodological biases.

The nutrient uptake by the seagrass leaves is demonstrated for most species, including those settled in nutrient-poor areas (Stapel et al. 1996, Touchette \& Burkholder 2000). In this study, the leaf uptakes of $\mathrm{NO}_{3}$ and $\mathrm{NH}_{4}$ were recorded at 0.05 and $0.1 \mu \mathrm{M}$ respectively.

In general, $\mathrm{N}$ uptake rates by seagrasses show a Michaelis-Menten relation to the concentration of substrate (Touchette \& Burkholder 2000). However, this relation is often established for a large range of concentrations regardless of the ambient concentrations in nitrate or ammonium. In the nutrient concentrations measured in Revellata Bay, such a relation between substrate concentration and uptake rates is very confusing. The variability of measurements is very important, and only the highest uptake rates of nitrate by leaves are correlated to the highest nitrate concentrations in the environment (Figs. $3 \& 6$ ). This peak of nitrate is very restricted in time and, consequently, the high variability of uptake rates observed in this study is not explained by the variation of substrate concentrations. Although this variability could result from uncertainty in nutrient concentration measurements, it is more likely a biological reality, demonstrating that other environmental and physiological factors influence nutrient uptake rates (e.g. light availability and photosynthetic rate, temperature, competition with other organisms).

Using the specific uptake rates and the $\mathrm{N}$ biomass obtained in the field experiments, we have calculated the uptake fluxes of nitrate and ammonium $\left(\mu \mathrm{g} \mathrm{N} \mathrm{m} \mathrm{N}^{-2}\right.$ $\mathrm{h}^{-1}$ ) by Posidonia oceanica leaves (Fig. 7). Uptake values in individual shoots vary between 0 and $120 \mu \mathrm{g} \mathrm{N}$ shoot $^{-1} \mathrm{~d}^{-1}$, which is similar to the uptake fluxes determined by Alcoverro et al. (2000) (0 to $113 \mu \mathrm{g} \mathrm{N}$ shoot $^{-1}$ $\mathrm{d}^{-1}$ ), from a $\mathrm{N}$ balance budget.

These fluxes show a high variability linked to experimental variability in the specific uptake rate and to the seasonality of biomass. For each period of measurement, it was possible to record incorporation of $\mathrm{N}$ by Posidonia oceanica leaves. This has important effects on the $\mathrm{N}$ dynamics of the plant. On one hand, according to the calculations of Alcoverro et al. (1995), the incorporation during winter (a period of low growth and high nitrate) explains the $\mathrm{N}$ concentration and content increase during this season, when the leaves of $P$. oceanica act as a storage organ, as in other Medi- terranean seagrasses such as Zostera noltii and Cymodocea nodosa (Kraemer \& Mazzella 1999). On the other hand, $P$. oceanica leaves take up nutrients all year round, not merely during the nitrate-rich and lowgrowth period (i.e. winter and early spring).

Between October 1998 and June 1999, a mean increase of the leaf nitrogen content of $11 \mathrm{mgN}$ shoot $^{-1}$ was measured. This quantity must be considered a minimum increase, as leaf loss, grazing and $\mathrm{N}$ leaching are not accounted for. The uptake of $\mathrm{N}$ by the leaves allows to meet this quantity only if we consider that the maximum uptake rate measured in March-April 1999 is maintained during a long period (some weeks) and if night uptake of nitrate occurs. These maximum uptake rates were only recorded during 1 wk in early spring 1999, and the night uptake of nitrate is small (Lepoint 2001). Leaf uptake is probably insufficient to meet the annual $\mathrm{N}$ requirement of Posidonia oceanica.

The root uptake of nitrogen is the second process examined in this study. The possession of roots in a nutrient-poor area is a clear competitive advantage compared to non-rooted primary producers (i.e. leaf epiphytes, phytoplankton, benthic macroalgae). Indeed, rooted plants can exploit the sediment as a nutrient source inaccessible to other primary producers (Hemminga 1998). An increase of the root biomass relative to the leaf biomass augments in the uptake capacity by increasing the volume of sediment exploited by the plant and the surface involved in root uptake (Casper \& Jackson 1997). However, Hemminga (1998) pointed out that high root biomass increases the oxygen needs and could drastically change the carbon 
Table 4. Posidonia oceanica. Annual N budget (first method) in Revellata Bay at $10 \mathrm{~m}$ depth. Annual $\mathrm{N}$ requirement $\left(\mathrm{g} \mathrm{N} \mathrm{m}^{-2} \mathrm{yr}^{-1}\right)$ is calculated from Pergent-Martini et al. (1994) (see details in the text). Annual root and leaf uptakes of ammonium and nitrate $\left(\mathrm{g} \mathrm{N} \mathrm{m}^{-2} \mathrm{yr}^{-1}\right)$ are calculated from ${ }^{15} \mathrm{~N}$ uptake and biomass measurements

\begin{tabular}{|lcc|}
\hline N annual requirement & & 9.7 \\
\hline Root uptake & $\mathrm{NH}_{4}$ & 26.0 \\
& $\mathrm{NO}_{3}$ & 4.1 \\
Leaf uptake & $\mathrm{NH}_{4}$ & 1.3 \\
& $\mathrm{NO}_{3}$ & 1.2 \\
\hline
\end{tabular}

balance in the plants. Thus, root biomass development is closely related to the photosynthetic activity in the leaves of the plant (Hemminga 1998).

The living belowground biomass measured in Revellata Bay was almost twice as high as the average maximum belowground biomass reported in the review of Duarte \& Chiscano (1999). The maximum leaf biomass is similar to the average maximum biomass reported for Posidonia oceanica by the same authors (550 vs $505 \mathrm{~g}_{\mathrm{dw}} \mathrm{m}^{-2}$ ). Thus, the ratio between belowground and leaf biomass in Revellata Bay is higher than the average reported by Duarte \& Chiscano (1999) (5.4 vs 3.2). Moreover, live roots were dominant (more than $50 \%$ of the living belowground biomass) in the samples compared to the live rhizome biomass. Generally, this proportion varies from 8 to $16 \%$ (Mateo \& Romero 1997, Mazzella et al. 1998).

It is not surprising that the root biomass should be relatively high at Revellata Bay. The nutrient concentrations in the pore water characteristic of the western coast of Corsica are 10 to 100 times lower than the concentrations measured in Italian and Spanish Posidonia oceanica meadows (e.g. Alcoverro et al. 1995, Kraemer \& Mazzella 1999). Lee \& Dunton (1999b) have shown that the root biomass is relatively higher at a site with low nutrient concentrations in the sediment, compared to a high-nutrient concentration site.

We calculated a $\mathrm{N}$ budget for Posidonia oceanica in Revellata Bay (Table 4). The $\mathrm{N}$ requirement of $P$. oceanica in Revellata Bay is calculated from the data of Pergent-Martini et al. (1994) obtained in this meadow at $10 \mathrm{~m}$ depth. We converted the leaf and belowground production data expressed in $\mathrm{g}_{\mathrm{dw}} \mathrm{m}^{-2} \mathrm{yr}^{-1}$ to $\mathrm{gN} \mathrm{m} \mathrm{N}^{-2}$ $\mathrm{yr}^{-1}$ using our $\mathrm{N}$ concentration measurements. This value is considered as the quantity of nitrogen annually required by the annual primary production as measured by Pergent-Martini et al. (1994). Annual uptake fluxes $\left(\mathrm{g} \mathrm{N} \mathrm{m}^{-2} \mathrm{yr}^{-1}\right)$ are calculated from the average specific uptake rates and biomasses, considering that $\mathrm{N}$ uptake takes place an average of $12 \mathrm{~h} \mathrm{~d}^{-1}$.

In fact, Table 4 shows that the root uptake calculated as described above is 3 times higher than the $\mathrm{N}$ required annually. The contribution of the roots to $\mathrm{N}$ incorporation is then clearly overestimated. As in many uptake experiments on the seagrass root, the measurements were done in the absence of sediment (e.g. Iizumi \& Hattori 1982, Lee \& Dunton 1999a). Moreover, the pump ensured water circulation in the chamber, and consequently nutrients were always available for root incorporation. In situ, this availability is mainly controlled by the diffusion rate of nutrients in the pore water (Stapel et al. 1996). In a Thalassia hemprichii meadow, these authors have shown that the $\mathrm{N}$ supplied by diffusion in $1 \mathrm{~h}$ represented only $5 \%$ of the uptake capacity of the roots during this time interval. They conclude that root uptake is primarily dependent on diffusion limits in the sediment and not on the uptake capacity of roots.

We have tried to calculate a second $\mathrm{N}$ budget considering that Posidonia oceanica has 3 principal mechanisms to meet its $\mathrm{N}$ requirement: leaf and root uptake, and internal recycling of $\mathrm{N}$ (Table 5). We measured the leaf uptake in this study, and the contribution of internal recycling has been estimated as $40 \%$ of the annual need by Alcoverro et al. (2000). Lepoint et al. (2002) have shown by another ${ }^{15} \mathrm{~N}$ tracer experiment that this contribution is the same in Revellata Bay. This value is higher than the average contribution of $20 \%$ by internal recycling in seagrasses (Hemminga et al. 1999). This difference could be related to the long life span of the $P$. oceanica leaves $(>150 \mathrm{~d})$, which allows a relatively efficient resorption of the $\mathrm{N}$ contained in adult

Table 5. Posidonia oceanica. Annual N budget (second method) at $10 \mathrm{~m}$ depth in Revellata Bay (Corsica)

\begin{tabular}{|lcl|}
\hline Requirement/process & Values/contribution & Source \\
\hline Annual N requirement & $9.7 \mathrm{~g} \mathrm{~N} \mathrm{~m}^{-2} \mathrm{yr}^{-1}$ & Calculated from Pergent-Martini et al. (1994) \\
Annual N leaf uptake & $2.5 \mathrm{~g} \mathrm{~N} \mathrm{~m}^{-2} \mathrm{yr}^{-1} / 26 \%$ of N requirement & Calculated from ${ }^{15} \mathrm{~N}$ uptake and biomass measurements \\
$\mathrm{N}$ internal recycling & $40 \%$ of N requirement & Alcoverro et al. (2000), Lepoint et al. (2002) \\
Annual N root uptake & $3.3 \mathrm{~g} \mathrm{~N} \mathrm{~m}^{-2} \mathrm{yr}^{-1} / 34 \%$ of $\mathrm{N}$ requirement & $\begin{array}{l}\text { Deducted from the contributions of N leaf uptake and } \\
\text { N internal recycling }\end{array}$ \\
\hline
\end{tabular}


leaves to contribute to the growth of young leaves (Alcoverro et al. 2000).

In this second budget, the contribution of the roots is slightly more important than leaf uptake. This agrees with the root biomass measured in Revellata Bay, which partly compensates the limitation of root uptake due to diffusion rates of nutrients in the sediment.

On the other hand, although the concentrations of $\mathrm{N}$ in the water column are low, the leaves of Posidonia oceanica act as a relatively efficient organ for $\mathrm{N}$ uptake. This pattern is different from the pattern of photosynthetic rates. Modigh et al. (1998) have shown that the photosynthetic capacity of leaves decreases as leaf age increases. Kraemer et al. (1997) have shown that the assimilation of $\mathrm{N}$ (i.e. the conversion of inorganic $\mathrm{N}$ into amino acids) mainly occurs in the growing leaves of $P$. oceanica. Therefore, the $\mathrm{N}$ incorporated by the adult leaves in excess to their needs is quickly transferred to these growing tissues (Alcoverro et al. 2000). Adult leaves, although they have reduced photosynthetic activity, contribute clearly to the leaf uptake of N. Borum et al. (1989) and Pedersen et al. (1997) have experimentally demonstrated this process in Zostera marina and Amphibolis antarctica. For the latter, Pedersen et al. (1997) showed that the transfer of $\mathrm{N}$ incorporated in old leaves is a continuous process representing $40 \%$ of the $\mathrm{N}$ needs of the young leaves.

The leaf biomass fluctuates seasonally and partly determines the variation of the $\mathrm{N}$ quantity incorporated by the leaves. For example, the specific uptake rates measured in June and October 1998 are similar, but the leaf uptake flux measured in June is higher than in October in relation to higher leaf biomass. The variations in specific uptake rates control leaf $\mathrm{N}$ fluxes during high nutrient concentration events, as in March 1999.

The $\mathrm{N}$ budget calculated for the Posidonia oceanica meadow of Revellata Bay is complex: several N pools and sources are involved, and leaves as well as roots participate in the uptake. This budget could be restricted to the nutrient-poor conditions encountered in Revellata Bay. Nevertheless, Lee \& Dunton (1999a,b) compared the $\mathrm{N}$ budget of 2 Thalassia testudinum meadows with different pore water nutrient concentrations and showed that the relative contribution of root and leaf uptake were the same in both meadows, although the absolute $\mathrm{N}$ fluxes were different. They related these observations to the modification of the ratio between root and leaf biomass, which equilibrates the respective contributions of the different organs. The fact that we measured such a modification in Revellata Bay compared to the continental meadows confirms the findings of Lee \& Dunton (1999a,b). Moreover, the contribution of internal recycling of $\mathrm{N}$ appears to be similar in the Catalan and Revellata Bay meadows (Alcoverro et al. 2000, Lepoint et al. 2002). Therefore, the budget elaborated for Revellata Bay meadow could apply to other meadows of the western Mediterranean, but such a generalisation needs more extensive experimental work. In this context, the ${ }^{15} \mathrm{~N}$ tracer methodology appears to be an important tool.

Acknowledgements. We are grateful to R. Biondo, who designed and constructed the experimental device. The authors wish to thank the staff of the oceanographic research station STARESO (Calvi, Corsica). We thank C. Beans and A. Borges for English improvements and helpful comments. The comments and suggestions by 3 anonymous referees improved the quality of a previous version of the manuscript. G.L. received grants from the 'Fonds de la Recherche pour l'Agriculture et l'Industrie' (F.R.I.A.). This study was funded by the French Community of Belgium (ARC 97/02-212) and the Belgian National Fund for Scientific Research (FRFC 2.4570.97).

\section{LITERATURE CITED}

Alcoverro T, Duarte CM, Romero J (1995) Annual growth dynamics of Posidonia oceanica contribution of largescale versus local factors to seasonality. Mar Ecol Prog Ser 120:203-210

Alcoverro T, Manzanera M, Romero J (2000) Nutrient mass balance of the seagrass Posidonia oceanica: the importance of nutrient retranslocation. Mar Ecol Prog Ser 194: $13-21$

Bay D (1984) A field study of the growth dynamics and productivity of Posidonia oceanica (L.) Delile in the Calvi Bay, Corsica. Aquat Bot 20:43-64

Borum J, Murray L, Kemp WM (1989) Aspect of nitrogen acquisition and conservation in eelgrass plants. Aquat Bot 35:289-300

Brohée M, Goffart A, Frankignoulle M, Henri V, Mouchet A, Hecq JH (1989) Variations printanières des communautés planctoniques en Baie de Calvi (Corse) en relation avec les contraintes physiques locales. Cah Biol Mar 30: $321-328$

Cancemi G, de Falco G, Pergent G (2000) Impact of a fish farming facility on a Posidonia oceanica meadow. Biol Mar Medit 7:341-344

Casper BB, Jackson RB (1997) Plant competition underground. Ann Rev Ecol Syst 28:545-570

Cloern JE (2001) Our evolving conceptual model of the coastal eutrophication problem. Mar Ecol Prog Ser 210: 223-253

Collos Y (1987) Calculation of ${ }^{15} \mathrm{~N}$ uptake rates by phytoplankton assimilating one or several nitrogen sources. Appl Radiot Isot 38 275-282

Dalla Via J, Sturmbauer C, Schönweger G, Sötz E, Mathekowitsch S, Stifter M, Rieger R (1998) Light gradients and meadow structure in Posidonia oceanica ecomorphological and functional correlates. Mar Ecol Prog Ser 163:267-278

Delgado O, Ballesteros E, Vidal M (1994) Seasonal variation in tissue nitrogen and phosphorus of Cystoseira mediterranea Sauvageau (Fucales, Phaeophycae) in the northwestern Mediterranean Sea. Bot Mar 37:1-9

Duarte CM (1990) Seagrass nutrient content. Mar Ecol Prog Ser 67:201-207

Duarte CM, Chiscano CL (1999) Seagrass biomass and production: a reassessment. Aquat Bot 65:159-174 
Dugdale RC, Wilkerson FP (1986) The use of ${ }^{15} \mathrm{~N}$ to measure nitrogen uptake in eutrophic oceans; experimental considerations. Limnol Oceanogr 31:673-689

Giraud G (1979) Sur une méthode de mesure et de comptage des structures foliaires de Posidonia oceanica (Linnaeus) Delile. Bull Mus Hist Nat Marseille 39:33-39

Glibert PM, Lipschultz F, McCarthy JJ, Altabet MA (1982) Isotope dilution models of uptake and remineralization of ammonium by marine plankton. Limnol Oceanogr 27: $639-650$

Gobert S, Defawe O, Lepoint G, Demoulin V, Bouquegneau JM (2001) Anthesis effects on Posidonia oceanica (L.) Delile phenology. Hydrobiologia 455:121-125

Hemminga MA (1998) The root/rhizome system of seagrasses: an asset and a burden. J Sea Res 39:183-196

Hemminga MA, Koutsaal BP, van Soelen J, Merks AGA (1994) The nitrogen supply to intertidal eelgrass (Zostera marina). Mar Biol 118:223-227

Hemminga MA, Marbà N, Stapel J (1999) Leaf nutrient resorption, leaf lifespan and the retention of nutrients in seagrass systems. Aquat Bot 65:141-158

Iizumi H, Hattori A (1982) Growth and organic production of eelgrass (Zostera marina L.) in temperate waters of the Pacific coast of Japan. III. The kinetics of nitrogen uptake. Aquat Bot 12:245-256

Kraemer GP, Mazzella L (1999) Nitrogen acquisition, storage and use by the co-occuring Mediterranean seagrasses Cymodocea nodosa and Zostera noltii. Mar Ecol Prog Ser 183:95-102

Kraemer GP, Mazzella L, Alberte RS (1997) Nitrogen assimilation and partitioning in the Mediterranean seagrass Posidonia oceanica. PSZN I: Mar Ecol 18:175-188

Lee KS, Dunton KH (1999a) Inorganic nitrogen acquisition in the seagrass Thalassia testudinum development of a whole-plant nitrogen budget. Limnol Oceanogr 44: 1204-1215

Lee KS, Dunton KH (1999b) Influence of sediment nitrogenavailability on carbon and nitrogen dynamics in the seagrass Thalassia testudinum. Mar Biol 134:217-226

Lepoint G (2001) Compétition pour l'azote inorganique entre le pelagos et le benthos d'un milieu côtier oligotrophe. Effets sur la dynamique de l'écosystème. PhD thesis, University of Liège

Lepoint G, Nyssen F, Gobert S, Dauby P, Bouquegneau JM (2000) Relative impact of a Posidonia seagrass bed and its adjacent epilithic algal community in consumer diet. Mar Biol 136:513-518

Lepoint G, Defawe O, Gobert S, Dauby P, Bouquegneau JM (2002) Experimental evidence for $\mathrm{N}$ recycling in the leaves of the seagrass Posidonia oceanica. J Sea Res (in press)

Editorial responsibility: Otto Kinne (Editor),

Oldendorf/Luhe, Germany
Lopez NI, Duarte CM, Vallespinos F, Romero J, Alcoverro T (1995) Bacterial activity in NW Mediterranean seagrass (Posidonia oceanica) sediments. J Exp Mar Biol Ecol 187: 39-49

Marbà N, Cebrian J, Enriquez S, Duarte CM (1996) Growth patterns of western Mediterranean seagrasses: speciesspecific responses to seasonal forcing. Mar Ecol Prog Ser 133:203-215

Mateo MA, Romero J (1997) Detritus dynamics in the seagrass Posidonia oceanica: elements for an ecosystem carbon and nutrient budget. Mar Ecol Prog Ser 151:43-53

Mazzella L, Guidetti M, Lorenti M, Buia MC, Zupo V, Scipione MB, Rismondo A, Curiel D (1998) Biomass partitioning in Adriatic seagrass ecosystems (Posidonia oceanica, Cymodocea nodosa, Zostera marina). Rapp PV Comm Int Explor Sci Mer Méditerr Monaco 35:562-563

Modigh M, Lorenti M, Mazzella L (1998) Carbon assimilation in Posidonia oceanica: biotic determinants. Bot Mar 41: $249-256$

Norro A (1995) Etude pluridisciplinaire d'un milieu côtier: approches expérimentale et modélisation de la Baie de Calvi (Corse). PhD thesis, University of Liège

Pedersen MF, Borum J (1993) An annual nitrogen budget for a seagrass Zostera marina population. Mar Ecol Prog Ser 101:169-177

Pedersen MF, Paling EI, Walker DI (1997) Nitrogen uptake and allocation in the seagrass Amphibolis antarctica. Aquat Bot 56:105-117

Pergent-Martini C, Rico-Raimondino V, Pergent G (1994) Primary production of Posidonia oceanica in the Mediterranean basin. Mar Biol 120:9-15

Skliris N, Goffart A, Hecq JH, Djenidi S (2001) Shelf-slope exchanges associated with a steep submarine canyon off Calvi (Corsica, NW Mediterranean Sea): a modelling approach. J Geophys Res 106:19883-19902

Stapel J, Aarts TL, van Duynhoven BHM, de Groot JD, van den Hoogen PHW, Hemminga MA (1996) Nutrient uptake by leaves and roots of the seagrass Thalassia hemprichii in the Spermonde Archipelago, Indonesia. Mar Ecol Prog Ser 134:195-206

Stapel J, Hemminga MA, Bogert CG, Maas YEM (2001) Nitrogen $\left({ }^{15} \mathrm{~N}\right)$ retention in small Thalassia hemprichii seagrass plots in an offshore meadow in South Sulawesi, Indonesia. Limnol Oceanogr 46:24-37

Terrados J, Williams SL (1997) Leaf versus root nitrogen uptake by the surfgrass Phyllospadix torreyi. Mar Ecol Prog Ser 149:267-277

Touchette BW, Burkholder JA M (2000) Review of nitrogen and phosphorus metabolism in seagrass. J Exp Mar Biol Ecol 250:133-167

Submitted: October 24, 2001; Accepted: February 26, 2002

Proofs received from author(s): July 3, 2002 